\title{
A Contingency Solution using Jet Grouting Barrier for a Dam under Risk of Piping in Brazil
}

\author{
S.M. Ludemann, R.S. Garcia, M.G.T. Barbosa, A.L.B. Cavalcante
}

\begin{abstract}
During routine inspection works in 2006 inspectors found resurgences of water at the toe of a small embankment dam named "Ribeirão do Gama", located at Brasília - DF. After technical visits, geotechnical engineers characterized these groundwater leakages as a piping process at an early stage. Intervention only began in 2015 due to obstacles that occasionally happen in public works. In consequence, the piping problem worsened. A geotechnical consultancy was contracted to design a solution. After analysis of field conditions, the consultancy decided to build overlapping columns by the Jet Grouting method. This paper presents a case study of the project and works treatment, detailing its design, construction, and monitoring.
\end{abstract}

Keywords: cut-off, earth dam, jet grouting, piping.

\section{Introduction}

According to the account of the oldest inhabitant of the region, the "Ribeirão do Gama" dam was constructed in the second half of the 1950s, simultaneously with the start of the construction of the federal capital of Brazil, Brasília. Brasília's government probably built this geotechnical structure to form a reservoir to serve as water supply for the necessary earthworks at the time. In this context, a dike was built with features of a temporary work and therefore had no sealing nor drainage devices, as would be normal in a permanent dam.

The dike formed a scenic lake of a considerable volume of water after the finalization of the main earthworks of Brasília. As there was a residential area near "Ribeirão do Gama", the dike was kept and later heightened, to allow the water surface also to increase, therefore configuring the dike as a small embankment dam. Later, already inserted in the "Fazenda Água Limpa", a property of the University of Brasília (UnB), the outlet water was used for agricultural purposes, providing water to the horticultural village "Vargem Bonita", and for human consumption downstream. Thus, the dam became a permanent structure.

"Ribeirão do Gama" dam has a length of $290 \mathrm{~m}$ and a height of $15 \mathrm{~m}$. It has a concrete side channel spillway located in its right abutment and a volute siphon water intake in its left abutment, for Vargem Bonita's supply. Figure 1 presents the aerial view of the site.

After 60 years of the construction of the embankment dam, in a routine inspection carried out in 2006, the technicians from UnB noted several points of leaking water at the toe of the downstream dam slope and eroded soil particles.
This fact, coupled with the advanced state of surface degradation of the upstream4 and downstream slopes, caused concern. A geotechnical engineering professor at UnB, Professor Pedro Murrieta, visiting the location, stated this situation had a high risk of developing a failure caused by piping, as had already occurred in many embankment dams in Brazil and abroad.

Because of difficulties in the contracting process, the recovery of the "Ribeirão do Gama" dam started only in 2015, when the risk of piping, which grew from six points of leakage in 2014 to fifteen in 2015, couldn't be ignored and a solution had to be implemented. The next sections present the main aspects of the design, and the construction works.

\section{Treatment of a Dam with Risk of Piping Failure}

Piping is a form of hydraulic failure, which is common in cases where erosion of soil by seepage forces occurs. Initially, it appears as a point of upwelling water, eroding the earth mass internally, carrying grains. The internal erosion results in the formation of a tube, usually in the form of a pipe. Hence this phenomenon was named piping.

These seepage forces are applied by unit volume, having the magnitude of $j=\gamma_{w} . i$, where $\gamma_{w}$ is the specific weight of water, and $i$ is the hydraulic gradient, which is given by $i=\Delta H / \Delta L$, where $\Delta H$ is the hydraulic head loss along the length $\Delta L$.

Sérgio Murari Ludemann, B.Sc., Technical Director, Ludemann Engenheiros Associados, São Paulo, SP, Brazil, e-mail: sergio@ludemann.com.br.

Robinson Siqueira Garcia, B.Sc., Civil Engineer, Ludemann Engenheiros Associados, São Paulo, SP, Brazil. e-mail: robin17sg@gmail.com.

Max Gabriel Timo Barbosa, M.Sc., Civil Engineer, Departamento de Engenharia Civil e Ambiental, Universidade de Brasília, Brasília, DF, Brazil. e-mail: maxtimo@gmail.com.

André Luís Brasil Cavalcante, Ph.D., Associate Professor, Departamento de Engenharia Civil e Ambiental, Universidade de Brasília, Brasília, DF, Brazil. e-mail: abrasil@unb.br.

Submitted on April 13, 2017; Final Acceptance on January 31, 2018; Discussion open until August 31, 2018

DOI: $10.28927 /$ SR.411017 


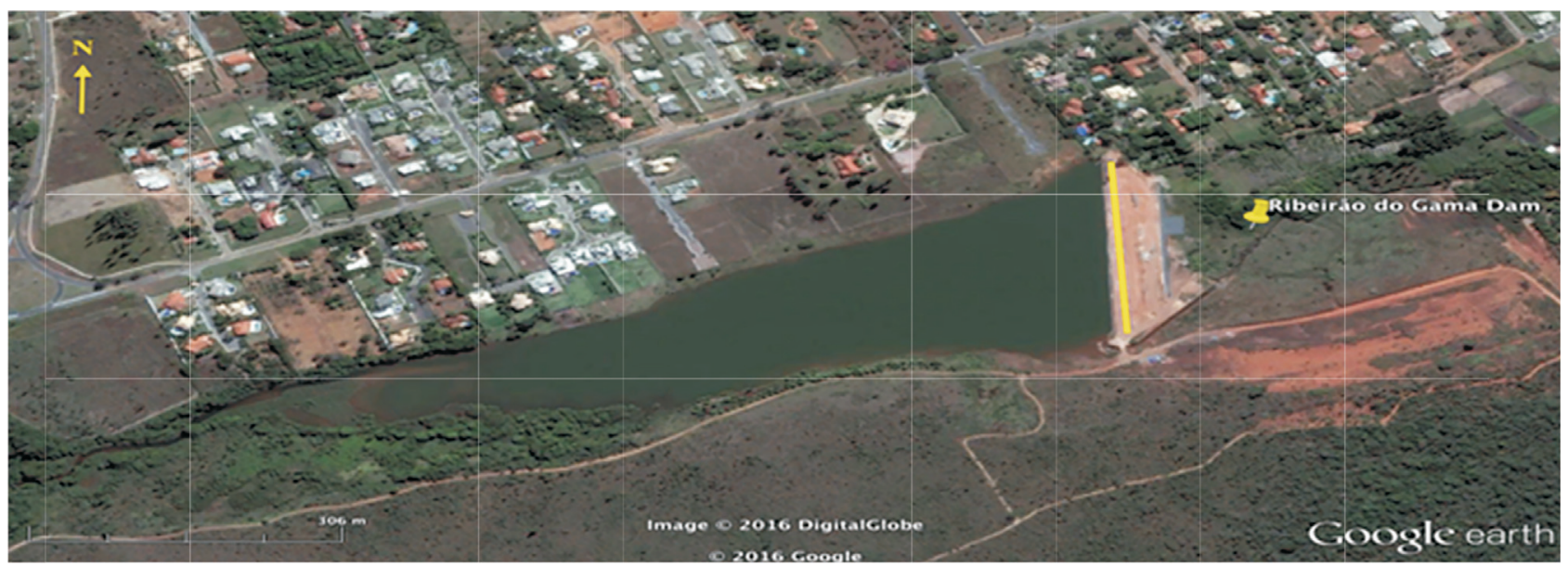

Figure 1 - Aerial view of the site (yellow line represents the axis of the dam).

In earth dams, it is not uncommon to have regions where the permeability coefficient $k_{i}$ is higher than the average permeability $k_{e q}$, making this region with higher permeability a preferential path to water flow. The flow velocity $\mathrm{v}$ is higher in this region and, therefore, the erosion of finer soil particles is more probable than in other regions. Consequently, the spacing between grains is higher, raising the maximum permeability of the region affected by this phenomenon.

When piping is progressing, the tendency is the upwelling of water in the dam's downstream surface and a point erosion, creating a hole into the affected volume of soil. As time goes by, the hole, resembling a pipe, progresses into the earth mass in a way opposite to the normal flow of the dam. As already described, this phenomenon is known as piping, generally defined as heave, internal erosion or backward erosion (Richards \& Reddy, 2007). In earth dams, it mainly occurs in the middle section of the dam and also in its foundation. In recent history, there have been accidents due to piping in several earth dams. One of the most notorious episodes was in the Teton Dam, in the United States of America, in 1976 (Richards \& Reddy, 2007).

As a reparation measure in similar occurrences, where there was evidence of a possible piping failure, an invasive ground improvement method is executed locally. The ground improvement methods applied in such situations consist in the alteration of the mechanical properties of the in-situ soil, giving to the earth mass and/or to the foundations better resistance, lower compressibility, and lower permeability.

Nevertheless, before the application of the most recommended techniques to obtain the desired results, such as Jet Grouting and Deep Soil Mixing, an assertive diagnosis of the problem was necessary. The diagnosis was performed using a detailed inspection of the upwelling water points, a topographic and bathymetric characterization of the dam slopes and the fulfillment of geotechnical surveys, lab and field tests which will allow to adequately typify the characteristics of the site underground and reduce risks (Lee \& Ishihara, 2016).

\section{In Situ Soil Geotechnical Description}

Geologically, the Gama Hydrological basin is settled into the silty-slate unity Grupo Paranoá. Geotechnical investigations done in the dam showed its foundations consisted of peat of very soft consistency, with a thickness between $2.0 \mathrm{~m}$ to $5.0 \mathrm{~m}$, on the main axis of the dam, overlaying a layer of a reddish clayey alluvium, of soft consistency, with a thickness between $1.0 \mathrm{~m}$ to $5.0 \mathrm{~m}$. Downstream, into the clayey soil region, appears a layer of sandy alluvium, of loose consistency, which could contain gravels, with thickness up to $6.0 \mathrm{~m}$. Below these alluvium layers existed a layer of residual soil, constituted by a variegated color sandy silt, of medium consistency, which could contain boulders, with thickness between $1.0 \mathrm{~m}$ (downstream and under the dam crest) to $6.0 \mathrm{~m}$ (upstream), overlying a layer of saprolite and the top of the rock matrix.

Regarding the dam, its foundation had different characteristics from the fill body, giving evidence that for its implementation the silty-sandy clay material was just dumped to allow the free traffic of the utilized equipment to construct the dam. Due to this procedure, the fill lower portion material had a soft consistency, with $\mathrm{N}$ values between 2-7 blow counts.

Also, due to the consolidation of the clayey alluviums, it is hypothesized there was a posterior complementation of the fill on the dam's crest. In Fig. 2 these observations are summarized in a typical section of "Ribeirão do Gama" dam, outlined based on the available borehole logs. 


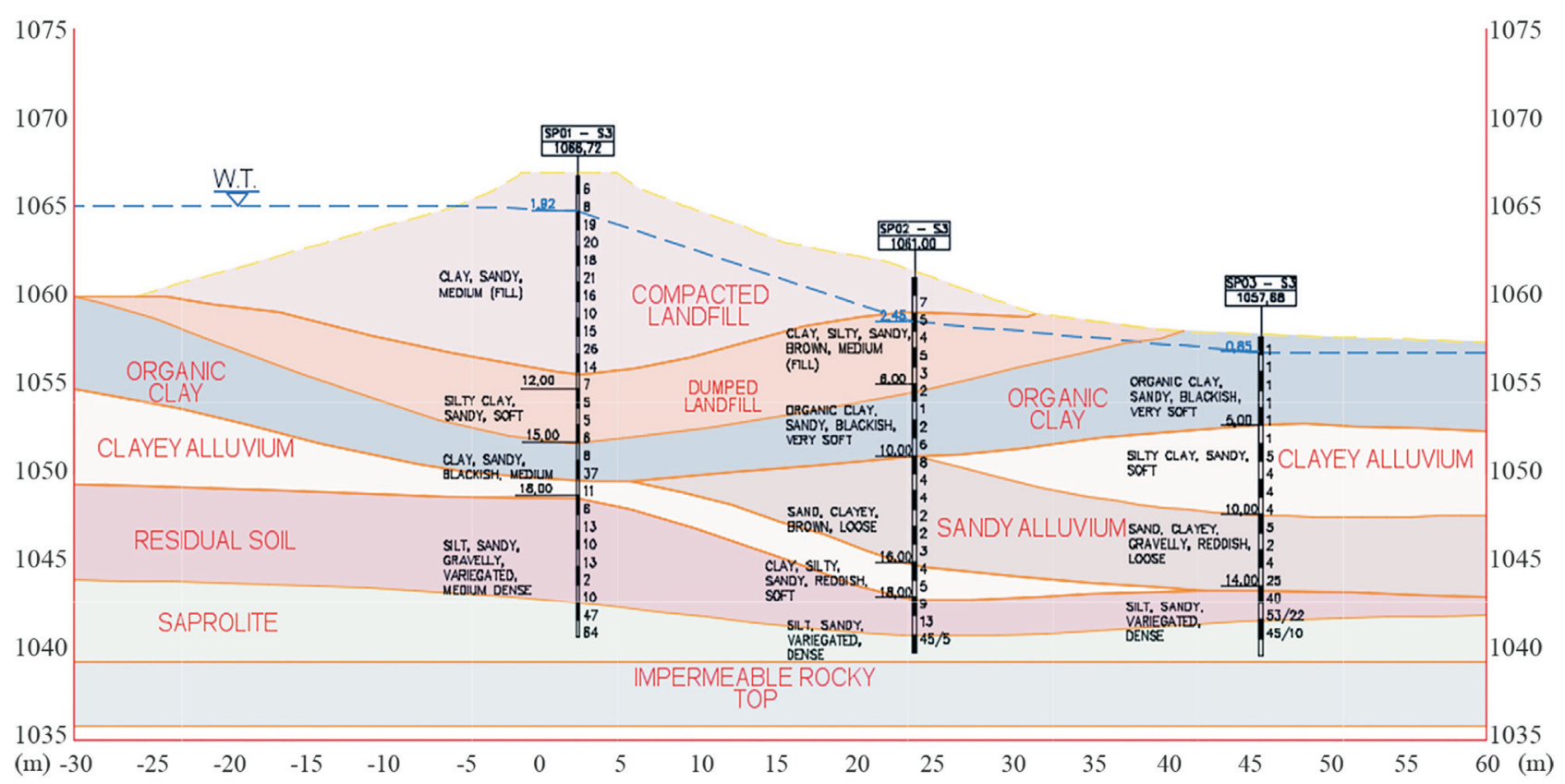

Figure 2 - Typical geotechnical section (Peg 9+00 m).

\section{Diagnosis}

\subsection{Dam stability analysis}

\subsubsection{Geotechnical parameters}

Piezocone field tests and laboratory tests (natural moisture, natural density, Atterberg limits, permeability and triaxial test CIU type) were necessary to obtain the geotechnical parameters of shear strength of the local underground layers. For the strength parameters of the cut-off columns, idealized as a possible solution for the flow problem, values were adopted from the literature (Nikbakhtan \& Osanloo, 2009; Saurer et al., 2011). Permeability parameters were firstly estimated from permeability values of previous projects; then they were calibrated with data obtained from piezometers already installed on site. Table 1 shows the values adopted in this design. Consolidation tests were also performed.

\subsubsection{Adopted assumptions}

The dam stability was studied by simulating the probable situation existent at the end of its construction to assess the adopted geotechnical parameters, considering at the time that the lower fill clayey layer was normally consolidated. Therefore, it had a lower resistance than noticed in tests conducted under the dam, probably similar to the resistance observed in the piezocone results on the dam downstream; also, it had a thickness higher than detected by surveys executed in the dam axis. Over the years, the clay layers were consolidated, making the dam foundation set- tle, for which an additional fill on the crest of the dam was necessary to maintain the original elevation.

\subsubsection{Stability analysis}

A stability analysis was performed since it was not clear if the dam would be stable in the long term. The Simplified Bishop method was used, aided by the software Slide 5.0 (Rocscience - Canada), with automatic search of the critical surface.

\subsubsection{Initial state - End of construction}

The graphical output of the stability analysis of the dam condition at the end of its construction is shown in Fig. 3 , resulting in a safety factor of 1.06 . It appears from this result that this dam was most likely built in stages, the first stage being the dumped landfill and the second stage the upper compacted embankment, confirming the chronology informed by locals.

\subsubsection{Situation at the time of design}

In the situation at the time of the design studies, the clayey and peaty soil under the soil structure was considered lightly consolidated. Thus, considering a gradation of resistances in the clay layers and estimating a critical phreatic line near the surface, the resulting safety factor is equal to 1.92, as shown in Fig. 4.

\subsubsection{Conclusions about the stability analysis}

The safety factor has undergone an increase in its value over time due to the strength gain caused by the consolidation of the clayey soil. Thus, considering the safety 
Table 1 - Adopted geotechnical parameters.

\begin{tabular}{|c|c|c|c|c|c|}
\hline Material & $\begin{array}{c}\text { Specific weight } \gamma \\
\left(\mathrm{kN} / \mathrm{m}^{3}\right)\end{array}$ & $\begin{array}{c}\mathrm{Su} \\
(\mathrm{kPa})\end{array}$ & $\begin{array}{c}\text { Cohesion } c^{\prime} \\
(\mathrm{kPa})\end{array}$ & $\begin{array}{c}\text { Friction angle } \phi \\
\left(^{\circ}\right)\end{array}$ & $\begin{array}{c}\text { Permeability } k \\
(\mathrm{~m} / \mathrm{s})\end{array}$ \\
\hline Compacted landfill & 17.0 & - & 33.0 & 37.0 & $2.0 \times 10^{-7}$ \\
\hline Dumped landfill & 16.0 & - & 17.0 & 37.0 & $6.0 \times 10^{-6}$ \\
\hline Sandy alluvium & 16.5 & - & 5.0 & 25.0 & $5.0 \times 10^{-5}$ \\
\hline Residual soil & 18.0 & - & 20.0 & 30.0 & $3.0 \times 10^{-6}$ \\
\hline Saprolite & 19.0 & - & 30.0 & 35.0 & $2.0 \times 10^{-6}$ \\
\hline Sand filter drain & 17.0 & - & 5.0 & 30.0 & $1.0 \times 10^{-3}$ \\
\hline Gravel toe drain & 19.0 & - & 5.0 & 40.0 & $5.0 \times 10^{-3}$ \\
\hline Cut-off columns & 18.0 & - & 40.0 & 30.0 & $1.0 \times 10^{-12}$ \\
\hline Normally consolidated organic clay & 14.0 & 17.0 & - & - & $5.0 \times 10^{-8}$ \\
\hline Lightly consolidated organic clay 1 & 15.0 & 25.0 & - & - & $2.0 \times 10^{-8}$ \\
\hline Lightly consolidated organic clay 2 & 16.0 & 40.0 & - & - & $1.0 \times 10^{-8}$ \\
\hline Normally consolidated clayey alluvium & 15.5 & 40.0 & - & - & $5.0 \times 10^{-8}$ \\
\hline Lightly consolidated clayey alluvium & 16.0 & 60.0 & - & - & $2.0 \times 10^{-8}$ \\
\hline 'Impervious' rock & - & - & - & - & $1.0 \times 10^{-12}$ \\
\hline
\end{tabular}

factor at the time of the design as satisfactory regarding the general stability of the dam, it was concluded that the main problem of the dam was water loss by the interface between the dumped landfill layer and the transition layers, with a potential risk of failure by piping.

Therefore, to reduce the flow of water significantly through the dam body, it was decided to make a cut-off. To make curtains with very low permeability in the studied dam, Slurry Walls, Deep Soil Mixing (DSM) and Jet Grouting techniques were considered, solutions much employed in this kind of work efficiently.

After analysis of field conditions, it was decided to build Jet Grouting columns. The reason for this choice stems from the fact that the solution in Jet Grouting would impose less critical stability conditions to the dam because of the lower weight of the necessary equipment and due to the fact that its execution method does not require much excavation in the dam body, aspects the solution in diaphragm walls did not meet. Further, supports the choice the fact Jet Grouting implementations, double fluid in the present case above, are efficient in forming columns in soil-cement with suitable permeability coefficients (AGI, 2012).

Croce \& Modoni (2007) reviewed the subject and presented accounts of remediation of existing dams, furnishing the design and construction details. Moreover, Sembenelli \& Sembenelli (1999) presented details of simi-

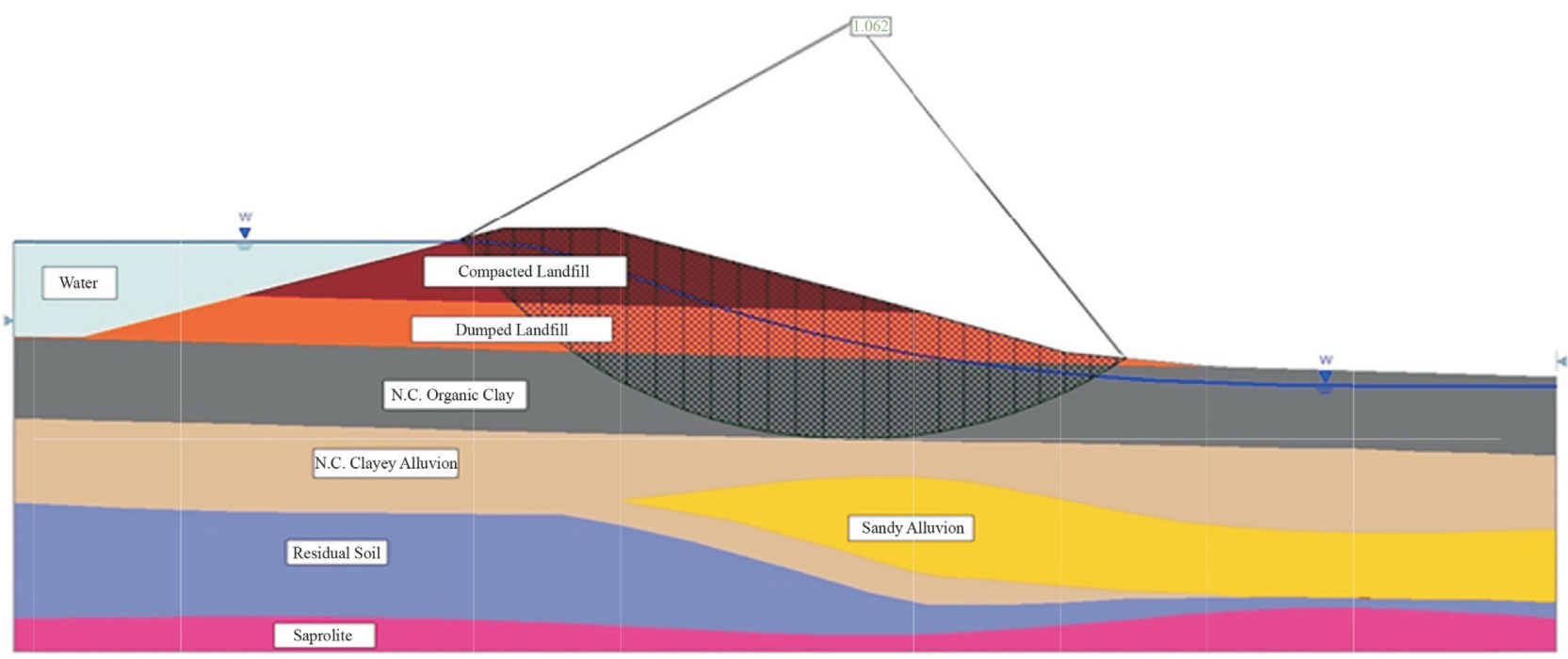

Figure 3 - End of construction stability analysis $(\mathrm{FS}=1.062)$. 


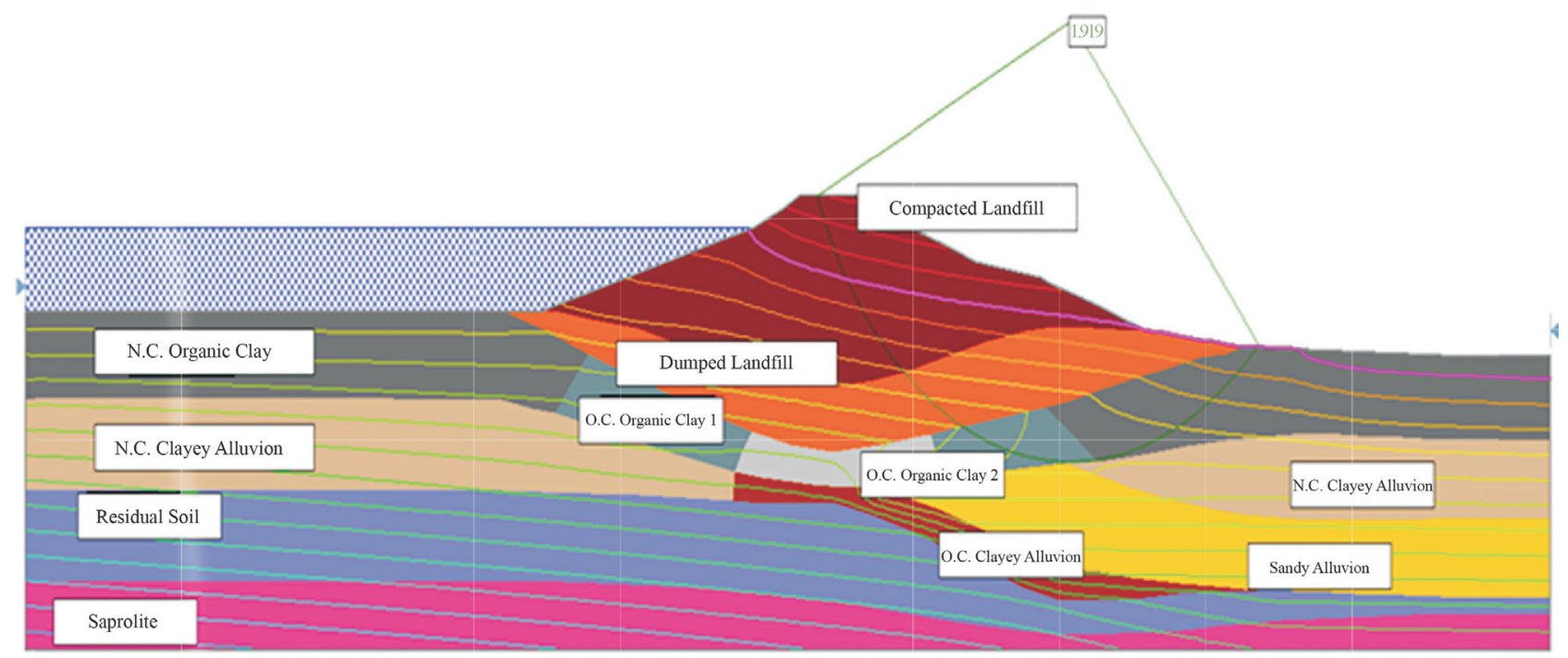

Figure 4 - Stability analysis of the dam's initial state $(\mathrm{FS}=1.92)$.

lar cutoff projects, allowing to design the proposed Jet Grouting cut-off. The 706 columns, with $80 \mathrm{~cm}$ diameter each, were to be built $40 \mathrm{~cm}$ overlapped in a single continuous row, with depths ranging from 10 to $22 \mathrm{~m}$, from the crest of the dam to its foundation. The single row cut-off design, running through the body of the dam, which is unprecedented in the author's knowledge of an advanced piping case in an existing dam, was possible due to the higher overlap of the columns (half of the diameter) than other cut-offs. Nevertheless, there was still a risk that the inherent variation of the diameters of the Jet Grouting columns would affect the overlapping and water tightness of the cut-off. The Jet Grouting cut-off was associated with a toe drainage system and the recovery of the downstream slope by a new fill to mitigate this risk.

\subsection{Flow analysis of the proposed solution}

As the main design concern was to assess the water flow through the body and foundation of the dam after the implementation of the Jet Grouting cut-off, the solution was analyzed by the Finite Element Method (FEM). FEM was assisted by the Slide software using the flow net calculation mode. Table 1 shows the coefficients of permeability adopted.

\subsubsection{Permeability parameters calibration}

As the permeability parameters were just estimated, it was decided to calibrate them with available field measurements of the dam's seepage flow. Fourteen Casagrande hydraulic piezometers were already installed prior to the start of the intervention, disposed as shown in Fig. 5. Table 2 presents the readings values.

With the data from Table 2, the flow nets of the embankment were drawn, adjusting some of the soil permeability parameters and the downstream headwater level to
Table 2 - Piezometers readings before the intervention.

\begin{tabular}{lccc}
\hline Piezometer & Peg $(\mathrm{m})^{*}$ & Piezometer depth $(\mathrm{m})$ & $\begin{array}{c}\text { Water level } \\
\text { recorded }(\mathrm{m})\end{array}$ \\
\hline P1 & $2+0.00$ & 6.68 & 4.20 \\
P2 & $5+0.00$ & 15.33 & 2.90 \\
P3 & $9+0.00$ & 22.10 & 6.00 \\
P4 & N. I. & 4.18 & 1.70 \\
P5 & N. I. & 3.35 & 1.60 \\
P6 & N. I. & 3.45 & 3.20 \\
P7 & $15+0.00$ & 7.70 & 2.90 \\
P8 & $15+0.00$ & 9.85 & 2.90 \\
P9 & $9+0.00$ & 10.00 & 4.20 \\
P10 & $5+0.00$ & 11.30 & 4.10 \\
P11 & $2+10.00$ & 3.75 & 2.00 \\
P12 & $5+0.00$ & 12.60 & 1.00 \\
P13 & $9+0.00$ & 16.20 & 1.14 \\
P14 & $15+0.00$ & 8.14 & On top \\
\hline
\end{tabular}

Peg: Piezometer location, e.g. $2+0.00 \mathrm{~m}$ represents $40 \mathrm{~m}$ from datum.

N.I.: Not informed in Fig. 5.

arrive at a combination that could best match the observed in situ water heads provided by the piezometers.

\subsubsection{Flow net for the situation at the time of design and for the proposed solution}

With the calibrated parameters and the geotechnical sections drawn, the design and definition of flow nets for each peg of the dam (i.e., each section $20.0 \mathrm{~m}$ spaced) was possible. Table 3 presents the estimated flow rates per dam section, before and after the imple- 


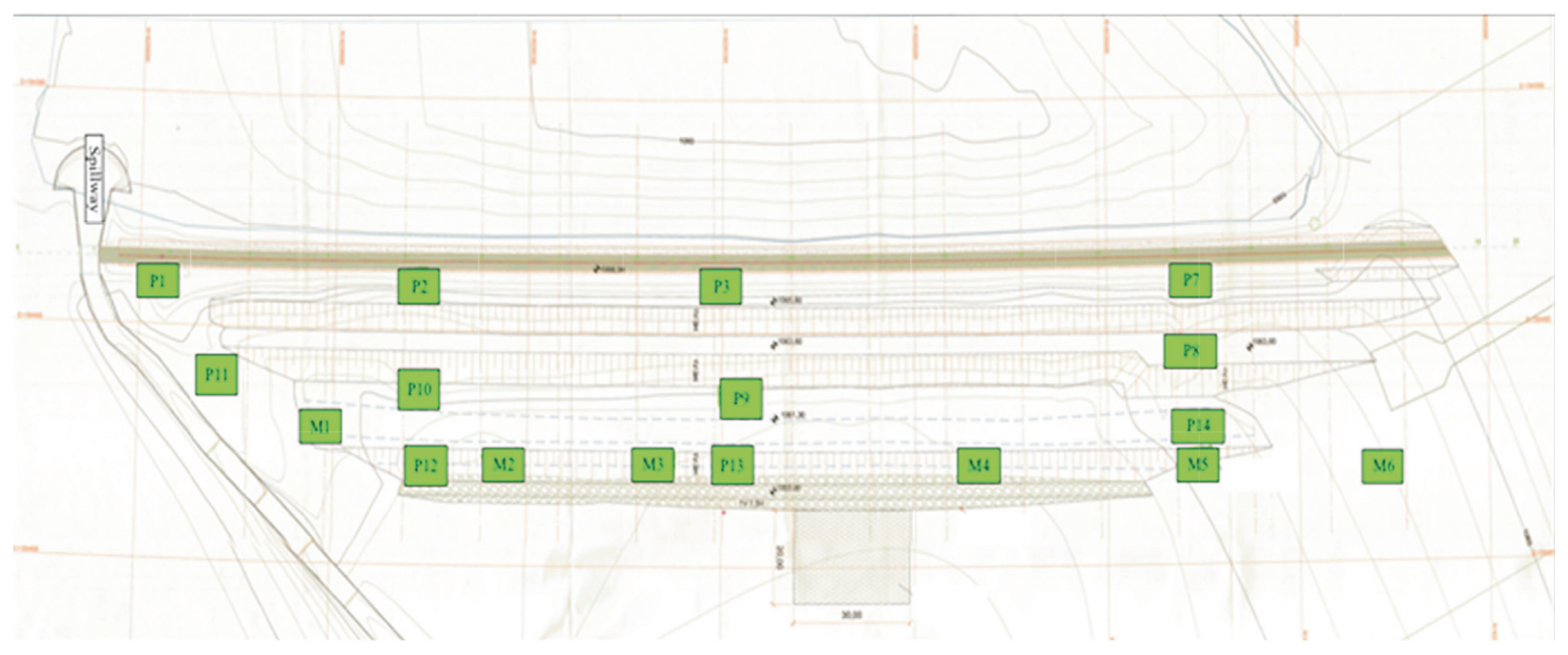

Figure 5 - Piezometers location in situ (P represents the piezometers and M the surface marks).

Table 3 - Flow rates estimate by the dam's sections in the condition at the time of design and the estimate after the project implementation.

\begin{tabular}{|c|c|c|c|c|c|c|}
\hline \multirow[t]{2}{*}{ Peg 9+00 m } & \multicolumn{3}{|c|}{ Initial flow rate $\left(\mathrm{m}^{3} / \mathrm{s} / \mathrm{m}\right)$} & \multicolumn{3}{|c|}{ Design flow rate $\left(\mathrm{m}^{3} / \mathrm{s} / \mathrm{m}\right)$} \\
\hline & Input (I) & Output (O) & $\Delta$ & Input (I) & Output (O) & $\Delta$ \\
\hline 0 & $7.11 \times 10^{-7}$ & $7.11 \times 10^{-7}$ & 0.00 & $7.11 \times 10^{-7}$ & $7.11 \times 10^{-7}$ & 0.00 \\
\hline 1 & $9.70 \times 10^{-7}$ & $7.14 \times 10^{-7}$ & $2.57 \times 10^{-7}$ & $7.10 \times 10^{-7}$ & $7.09 \times 10^{-7}$ & $7.70 \times 10^{-16}$ \\
\hline 2 & $1.18 \times 10^{-6}$ & $1.16 \times 10^{-6}$ & $1.70 \times 10^{-8}$ & $8.96 \times 10^{-7}$ & $9.07 \times 10^{-7}$ & 0.00 \\
\hline 3 & $1.67 \times 10^{-6}$ & $1.49 \times 10^{-6}$ & $1.77 \times 10^{-7}$ & $1.37 \times 10^{-10}$ & $8.83 \times 10^{-11}$ & $4.84 \times 10^{-11}$ \\
\hline 4 & $2.03 \times 10^{-6}$ & $1.97 \times 10^{-6}$ & $6.10 \times 10^{-8}$ & $1.59 \times 10^{-10}$ & $9.67 \times 10^{-11}$ & $6.24 \times 10^{-11}$ \\
\hline 5 & $2.68 \times 10^{-6}$ & $1.59 \times 10^{-6}$ & $1.10 \times 10^{-6}$ & $1.93 \times 10^{-10}$ & $1.87 \times 10^{-10}$ & $5.54 \times 10^{-12}$ \\
\hline 6 & $2.79 \times 10^{-6}$ & $1.47 \times 10^{-6}$ & $1.32 \times 10^{-6}$ & $2.24 \times 10^{-10}$ & $2.24 \times 10^{-10}$ & 0.00 \\
\hline 7 & $3.20 \times 10^{-6}$ & $1.47 \times 10^{-6}$ & $1.73 \times 10^{-6}$ & $4.56 \times 10^{-7}$ & $4.56 \times 10^{-7}$ & 0.00 \\
\hline 8 & $4.33 \times 10^{-6}$ & $2.94 \times 10^{-6}$ & $1.40 \times 10^{-6}$ & $1.81 \times 10^{-6}$ & $1.81 \times 10^{-6}$ & 0.00 \\
\hline 9 & $4.20 \times 10^{-6}$ & $2.37 \times 10^{-6}$ & $1.83 \times 10^{-6}$ & $1.52 \times 10^{-6}$ & $1.52 \times 10^{-6}$ & 0.00 \\
\hline 10 & $4.67 \times 10^{-6}$ & $2.26 \times 10^{-6}$ & $2.41 \times 10^{-6}$ & $1.75 \times 10^{-6}$ & $1.68 \times 10^{-6}$ & $6.88 \times 10^{-8}$ \\
\hline 11 & $4.68 \times 10^{-6}$ & $4.22 \times 10^{-6}$ & $4.54 \times 10^{-7}$ & $1.45 \times 10^{-6}$ & $1.41 \times 10^{-6}$ & $3.38 \times 10^{-8}$ \\
\hline 12 & $5.36 \times 10^{-6}$ & $1.98 \times 10^{-6}$ & $3.37 \times 10^{-6}$ & $1.18 \times 10^{-6}$ & $9.65 \times 10^{-7}$ & $2.15 \times 10^{-7}$ \\
\hline 13 & $5.11 \times 10^{-6}$ & $3.41 \times 10^{-6}$ & $1.70 \times 10^{-6}$ & $1.67 \times 10^{-10}$ & $1.38 \times 10^{-10}$ & $2.94 \times 10^{-11}$ \\
\hline 14 & $3.90 \times 10^{-6}$ & $2.96 \times 10^{-6}$ & $9.36 \times 10^{-7}$ & $1.29 \times 10^{-10}$ & $1.01 \times 10^{-10}$ & $2.72 \times 10^{-11}$ \\
\hline 15 & $1.97 \times 10^{-6}$ & $1.36 \times 10^{-6}$ & $6.10 \times 10^{-7}$ & $1.04 \times 10^{-10}$ & $7.13 \times 10^{-11}$ & $3.31 \times 10^{-11}$ \\
\hline 16 & $1.39 \times 10^{-6}$ & $1.18 \times 10^{-6}$ & $2.10 \times 10^{-7}$ & $1.15 \times 10^{-9}$ & $5.68 \times 10^{-11}$ & $1.10 \times 10^{-9}$ \\
\hline 17 & $8.12 \times 10^{-7}$ & $8.12 \times 10^{-7}$ & $3.00 \times 10^{-11}$ & $7.43 \times 10^{-11}$ & $2.85 \times 10^{-11}$ & $4.59 \times 10^{-11}$ \\
\hline 18 & $4.50 \times 10^{-7}$ & $4.50 \times 10^{-7}$ & 0.00 & $4.87 \times 10^{-11}$ & $2.24 \times 10^{-11}$ & $2.63 \times 10^{-11}$ \\
\hline 19 & $4.06 \times 10^{-7}$ & $4.06 \times 10^{-7}$ & 0.00 & $4.06 \times 10^{-7}$ & $4.06 \times 10^{-7}$ & 0.00 \\
\hline Total $\left(\mathrm{m}^{3} / \mathrm{s}\right)$ & $1.04 \times 10^{-3}$ & $6.88 \times 10^{-4}$ & $3.52 \times 10^{-4}$ & $2.07 \times 10^{-4}$ & $2.00 \times 10^{-4}$ & $6.40 .10^{-6}$ \\
\hline
\end{tabular}

mentation of the proposed solution. The input flow rate (I) is the flow rate which occurs in the vertical section where the upstream piezometric elevation $(+1,065.00 \mathrm{~m})$ is the same as the reservoir level. The output flow rate (O) is the one that flows under the toe of the downstream slope. The outflow by the dam's downstream surface, called $\Delta$, is the difference between the input and output flow rates, $(\mathrm{I})$ and $(\mathrm{O})$, not only in the previous condition, before the treatment, but also in the final condition of the project. In Fig. 6 the results are graphically presented, 


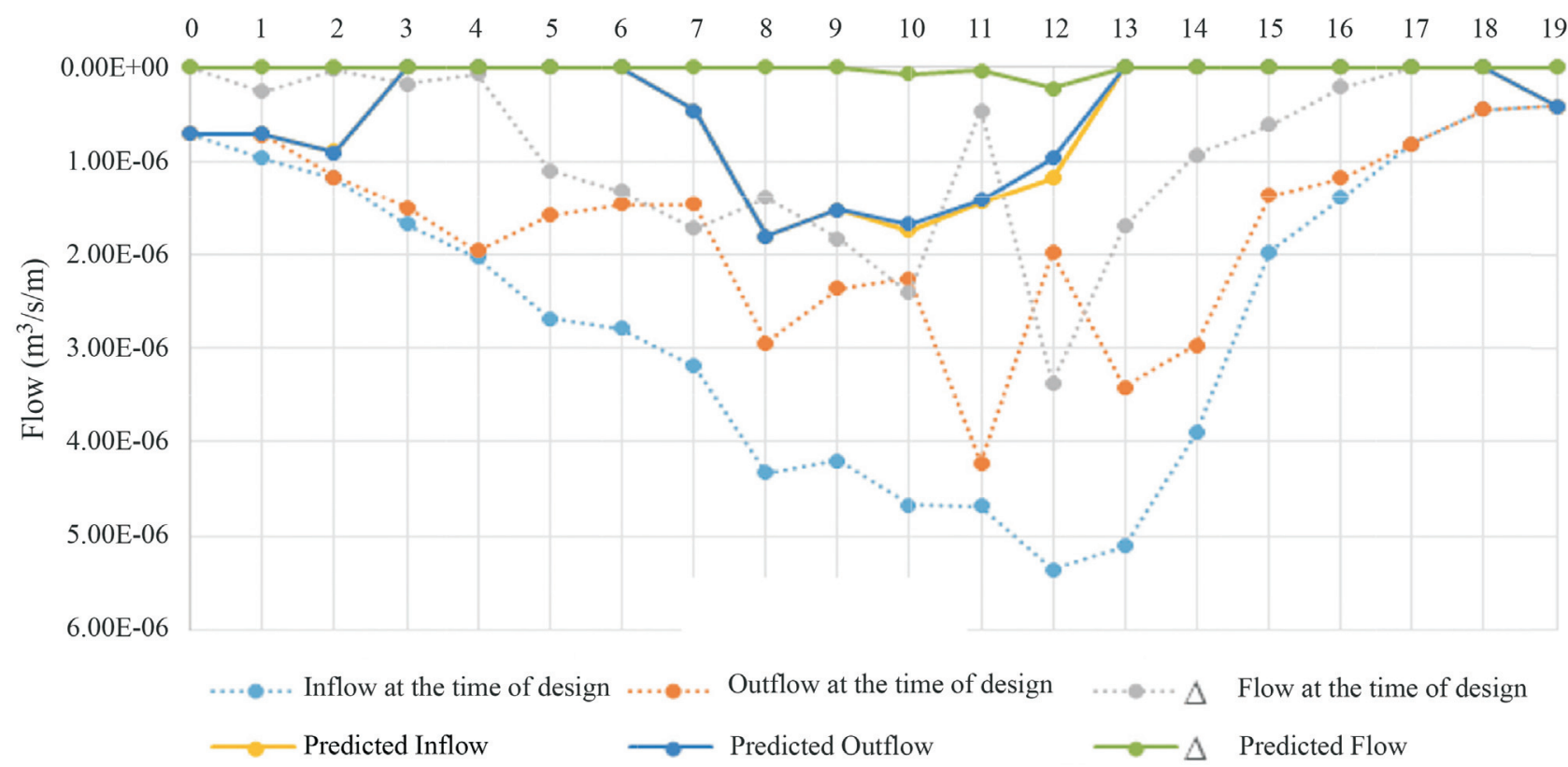

Figure 6 - Flow rates estimate per dam section.

and in Fig. 7 the input and output sections are presented schematically.

Figure 6 shows the proposed solution would substantially decrease the downstream water loss, almost eliminating the existent flow in the dam's foundation.

\subsection{Stability analysis of the proposed solution}

The most critical section refers to Peg $9+0.00 \mathrm{~m}$, which is the location with the lowest downstream ground level and the highest thickness of organic peat.

Figure 7 presents the estimated flow net by that section. Adopting the strength parameters shown in Table 1, a stability analysis of the downstream slope at Peg $9+0.00 \mathrm{~m}$ was made. The graphical output of this stability analysis is presented in Fig. 8, resulting in a factor of safety FS $=2.00$, considered satisfactory.

\subsection{Conclusions regarding the proposed solution}

According to design estimates, the Jet Grouting cutoff will decrease the leakage in the dam's foundations by $80 \%$ and the water flow near the dam's toe by $98 \%$. The remaining water flow will be collected by the draining bed and by the toe drain. Thereby, the design controlled and hampered the downstream leakage problem and the piping process.

\section{Solution Implementation}

\subsection{Implementation methodology}

Despite the proven efficacy of the chosen solution for cut-offs, this solution was in a single row, not in two or three rows as in other projects (Sembenelli \& Sembenelli, 1999; Croce \& Modoni, 2007; Guatteri et al., 2012). In "Ribeirão do Gama" dam the execution team was con-

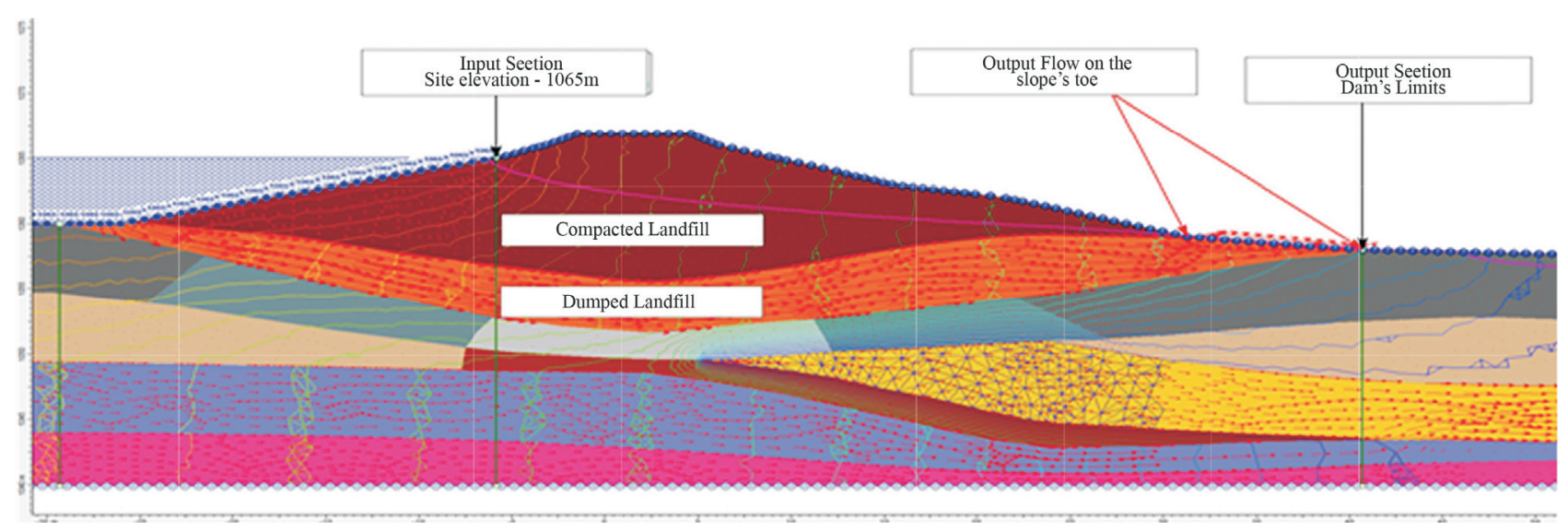

Figure 7 - Predicted flow net (Peg 9+00 m). 


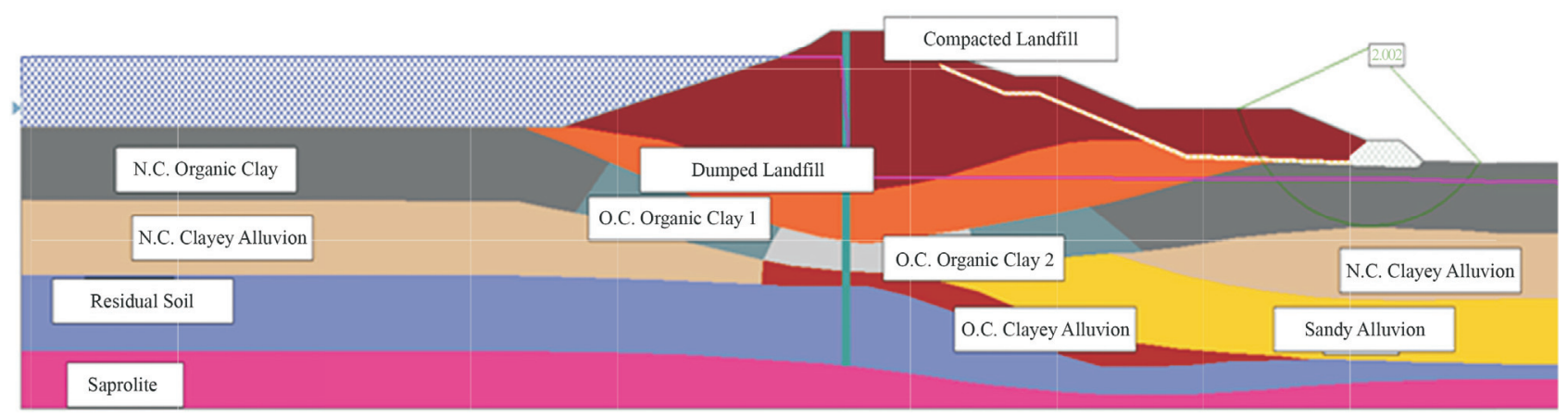

Figure 8 - Stability analysis of the dam's final state $(F S=2.00)$.

cerned mainly with two aspects, besides the recommended Jet Grouting control factors by AGI (2012):

- significant heterogeneity condition of the subsoil, with the presence of peat;

- possible lack of overlapping between columns.

It is added to these difficulties the existence of buried water intakes and tree roots in the dam body, additional triggering factors which can increase the probability of a failure by piping.

To surpass these aforementioned challenges, as whole soil-cement columns were formed with the parameters defined in the project, there was a need to follow rigorous methods of execution and control recommended by $\mathrm{ABEF}$ (2012) to avoid deviation and diameter variation of the columns, which can occur in Jet Grouting works (Croce \& Modoni, 2007). Thus, the method of implementing Jet Grouting columns was analyzed to obtain sufficient information to achieve an engineering solution with high performance. The execution of Jet Grouting columns can be subdivided into three steps, as shown in Fig. 9.

- Ground drilling by rotation of the rods set, usually of $10 \mathrm{~cm}$ diameter, and triconed drill bit mandrel, parallel with the water flow (500 1/ min) until the design depth. A metallic sphere closes the water injection nozzle;

- Grout injection at high pressures, which was enveloped by compressed air, to produce a high speed combined stream, eroding the ground and providing the interaction of cement grout with the earth mass;

- The rotational rise of the drill stem with step increase, rotation and speed calibrated to obtain columns with the desired parameters.

Several precautions are recommended to minimize instabilities of the Jet Grouting treatment of earth mass. Not only the parameters recommended by AGI (2012) must be considered, but also the diameter of the rod, the type of drill bit, the volume of the drilling water and the internal mechanism of the injection machinery to be used. These factors were considered for the choice of the Jet Grouting equipment.

Another aspect observed for the execution was the process of formation of columns. Because they are not formed immediately, as the Jet Grouting process forms col- umns with sufficient hardness to resist lateral injections only after a curing process of 48 hours, the execution method required columns spaced in a manner so that the execution of a column did not interfere with the curing of the other, as shown in Fig. 10.

According to AGI (2012), this method of making alternate boreholes, called "fresh in hard", shown in Fig. 10, requires special control. This caution is justified because of the possibility of the so-called "shadow effect" between the columns, a phenomenon caused by the difficulty of the jet to erode the earth mass outlining the primary columns $(\mathrm{P})$, with the possibility of formation of secondary columns (S) with a diameter lower than desired. Then, after forming and curing the primary columns, the space between them, formed by secondary columns, was filled until achieving the design's desired overlapping. So sometimes the injection of secondary columns was done with slightly higher pressures than those used in primary columns.

\subsection{Execution and control parameters}

The technology parameters were monitored to obtain $0.8 \mathrm{~m}$ diameter columns with a permeability coefficient low enough to reduce the water flow through the dam foundation, besides presenting adequate compressive strength. For this it was considered the AGI (2012) and ABEF (2012) recommendations; also, the experience of the designer and

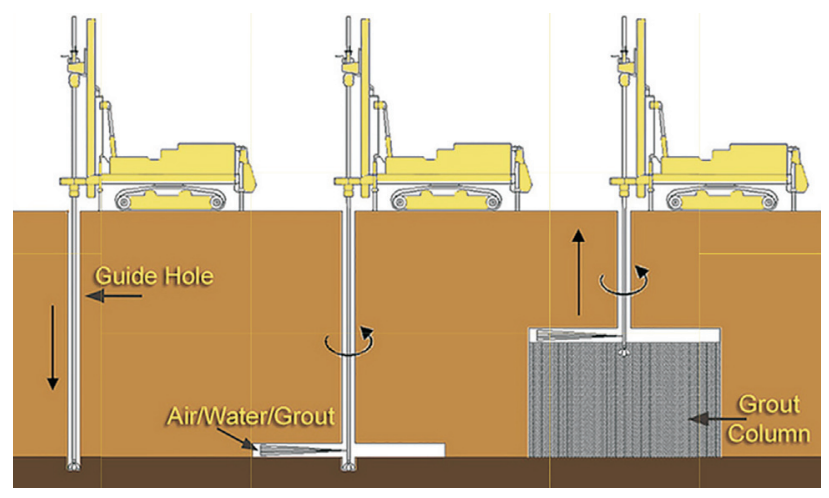

Figure 9 - Jet Grouting methodology (U.S. Army illustration by Todd Plain/Released). 


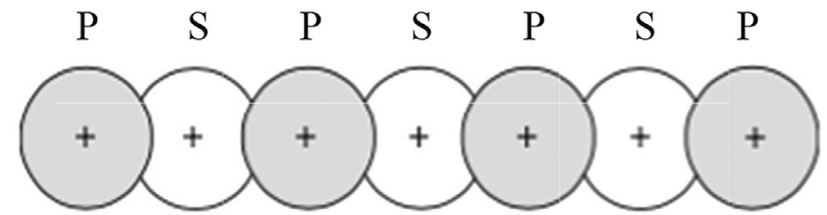

Figure 10 - "Fresh in hard" method, in which primary $(\mathrm{P})$ columns are built first to the posterior closing of the Jet Grouting curtain with the implementation of secondary (S) columns (AGI, 2012).

the contractor in works of Jet Grouting was crucial. Thus, Table 4 presents the initial parameters.

After the establishment of these parameters, trial columns were made in a location with a similar geology of the dam site but unaffected by piping. The design predicted bentonite as an additive meant to improve the water tightness of the cut-off, as seen in Guatteri et al. (2012). Nevertheless, as the bentonite slowed the curing process, and there was a risk of washout of the mix, it was decided not to utilize the bentonite and lower the w/c ratio to 0.7 . Thus, these corrected parameters were adopted to perform the work, yielding an average soil-cement column diameter of $0.8 \pm 0.1 \mathrm{~m}$, mitigating the washout of the mix, as shown in Fig. 11.

Due to the heterogeneity of the subsoil, the operation parameters were reassessed continuously and compared with the design parameters to ensure the Jet Grouting process formed columns with the desired diameter, permeability, strength, uniformity and spacing. The injection pressure was carefully monitored, so the inherent instability of the Jet Grouting process was minimized, reducing the risk of new communication paths between the upstream and the downstream of the dam.

Another object of observation in work was the reflux mud, arising from drilling with water since from the coloring of this mud was possible to estimate if the soil was

Table 4 - Initial Jet Grouting parameters.

\begin{tabular}{lc}
\hline Parameter & \\
\hline Rise step of the rods $(\mathrm{m})$ & 0.05 \\
Rod rise velocity (m/s) & 0.006 \\
Rod rotation (rpm) & 8 \\
Rod rotations per step (rpm/step) & 1.07 \\
Nozzle diameter (m) & 2.5 \\
Nozzle number & 2 \\
Grout injection pressure (MPa) & 15 \\
Air pressure $(\mathrm{MPa})$ & 1 \\
Grout flow rate (m³/s) & $1.2 \times 10^{-3}$ \\
w/c - by weight & 1.0 \\
Bentonite addition by weight $(\%)$ & 2.0 \\
\hline
\end{tabular}

found near those described in the geological investigations used in the preparation of the project.

\section{Monitoring and Instrumentation of the Implementation}

\subsection{Initial considerations}

The recovery of "Ribeirão do Gama" earth dam, required particular attention, due to the exacerbated process of subsurface retro erosion and because during the dam construction works, at the end of the 1950s, the implementation wasn't carefully accompanied, a fact that led to formation of soil layers with improper parameters for an embankment dam. According to data from Perini (2009), $36 \%$ of zoned earth dams' failures are by piping.

In this case study, besides the fact the dam had shown several signs of subsurface retro erosion, the structure also had several trees downstream, with water intakes passing in its middle section, factors which could disturb its recovery. Furthermore, the design of the Jet Grouting cut-off constructed in a single continuous row for an advanced piping problem was unprecedented.

Thus, due to the high risk of the dam recovery solution implementation, adequate instrumentation and monitoring specifications were necessary. In this way designers and contractors could take expeditious technical decisions correctly and have greater confidence in the pace of work.

\subsection{Instrumentation}

Bassett (2012) classifies the instrumentation of geotechnical works into three types: passive monitoring, realtime monitoring for building control and monitoring for safety. In the case of "Ribeirão do Gama" dam, the instrumentation falls in the first two classes, since there were previous calculations concerning the behavior of the flow passing through the dam in the design phase and also a real-time instrumentation for adjustments of execution parameters based on data of piezometers and displacements. Consequently, if measurements from different field instruments were different from the input values previously calculated, remedial actions could be made.

Therefore, to provide monitoring with sufficiently accurate reporting provision for the evaluation of "Ribeirão do Gama" dam, electric vibrating wire piezometers, surface marks, and inclinometers were installed.

The design required the installation of piezometers for evaluating the performance of the work regarding the flow, so water passing through the dam had similar parameters of magnitude and direction provided by the project. Moreover, it was possible to assess if the intervention resulted in the expected water head drop, with the elimination of the piping process, also assessing if the constructed cut-off could stop the flow through the dam body. For this, the designers set with the topography team key points for installation of equipment: the abutments, the places where 


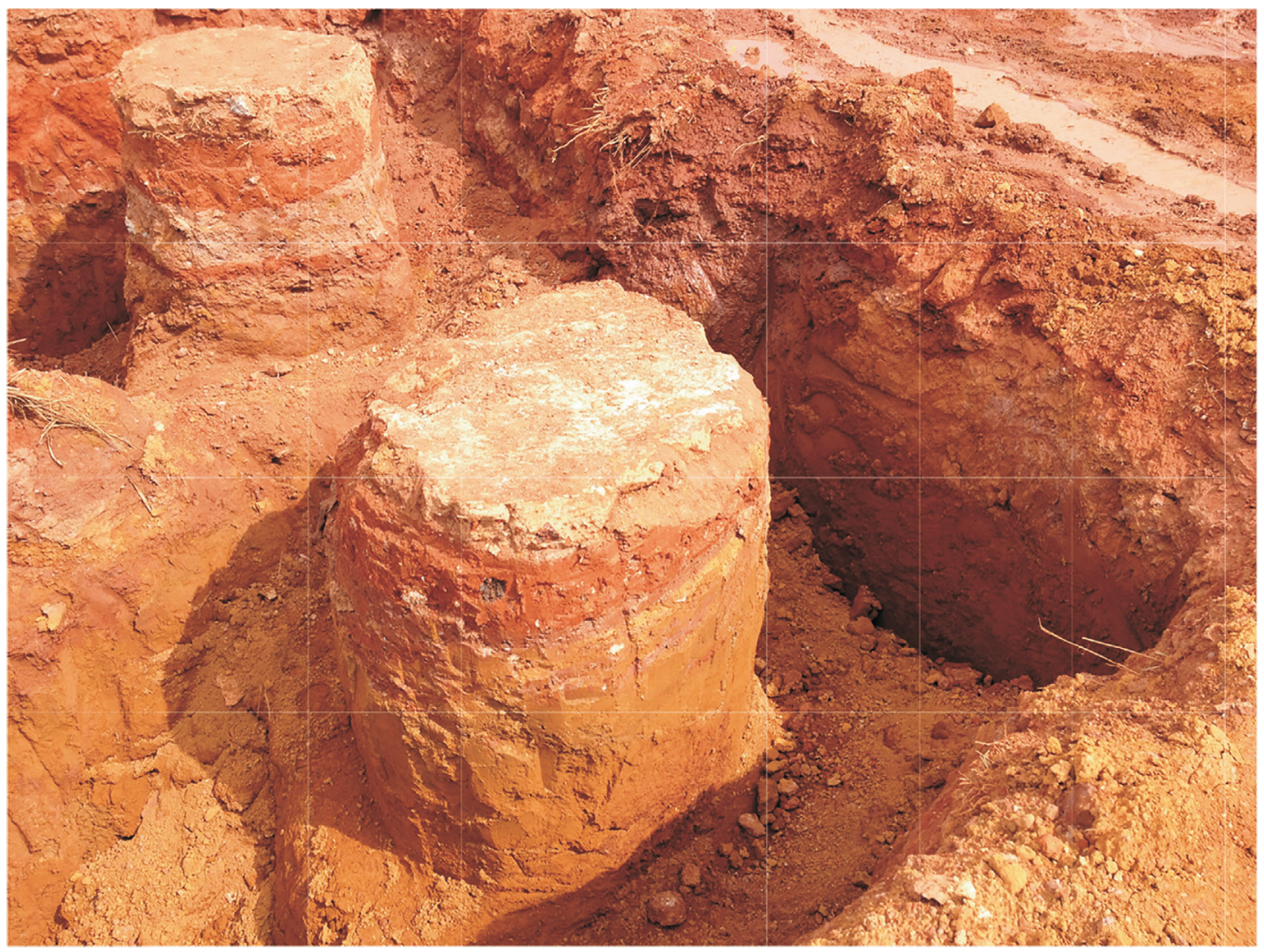

Figure 11 - Trial Jet Grouting columns.

the points of piping manifested with more intensity and places near the water intakes.

Regarding the surface marks and inclinometers, they were installed to provide data related to the local and global stability of the dam.

The surface marks were sensitive enough for small movements of the downstream slope to be detected, so that the Jet Grouting works could be optimized. Thus, the surface marks provided data from the vertical movements of the dam embankments and propitiated the detection of unstable ground, which required extra caution.

Meanwhile, the inclinometers with two axes of measurements, monitored dam movements in the horizontal, normal and longitudinal directions, complementing the leveling of surface marks, allowing a three-dimensional analysis of displacements. The design required the installation of inclinometers in critical sections where stability was the main concern, especially those dam sections resting on peat.

Thus, through the analysis of the instrumentation data, collected twice daily, the monitoring and evaluation of the behavior of the dam were possible, and the execution team could make adjustments into the previously established executive sequence.

\subsection{Monitoring}

The design required constant monitoring of the dam to aid the continuation of the work. With the continuous evaluation of data generated by instruments, more confident technical decisions could be made. In Figs. 12 to 15, it is presented examples of plots generated by the monitoring at the time of the intervention.

These instruments generated necessary data for the accompaniment of the works. Nevertheless, since the Jet Grouting process leaves the object of its intervention momentarily less stable, by eroding a soil column before the strength of the JG column is fully set, it was required a careful observation of regions on the vicinity of the equipment, complementing the instrumentation.

The inclinometers sometimes displayed anomalous behavior. However, such behavior, as noticed by the execution and instrumentation team, originated from movements and activities of the equipment employed in the works. Some explanations of unexpected behaviors detected from the instrumentation data were made possible.

It was concluded that the effects reported were mainly due to the action of the Jet Grouting machine, as its execution sequence may induce small cracks and vibrations from the high pressures used in the injection process of this type of treatment.

From this continuous monitoring by the team involved in the recovery of "Ribeirão do Gama" dam, an abandoned anthill, of large dimensions, inside the dam body, was detected as a generator of instabilities. The discovery of the anthill led to detection of other voids nearby 


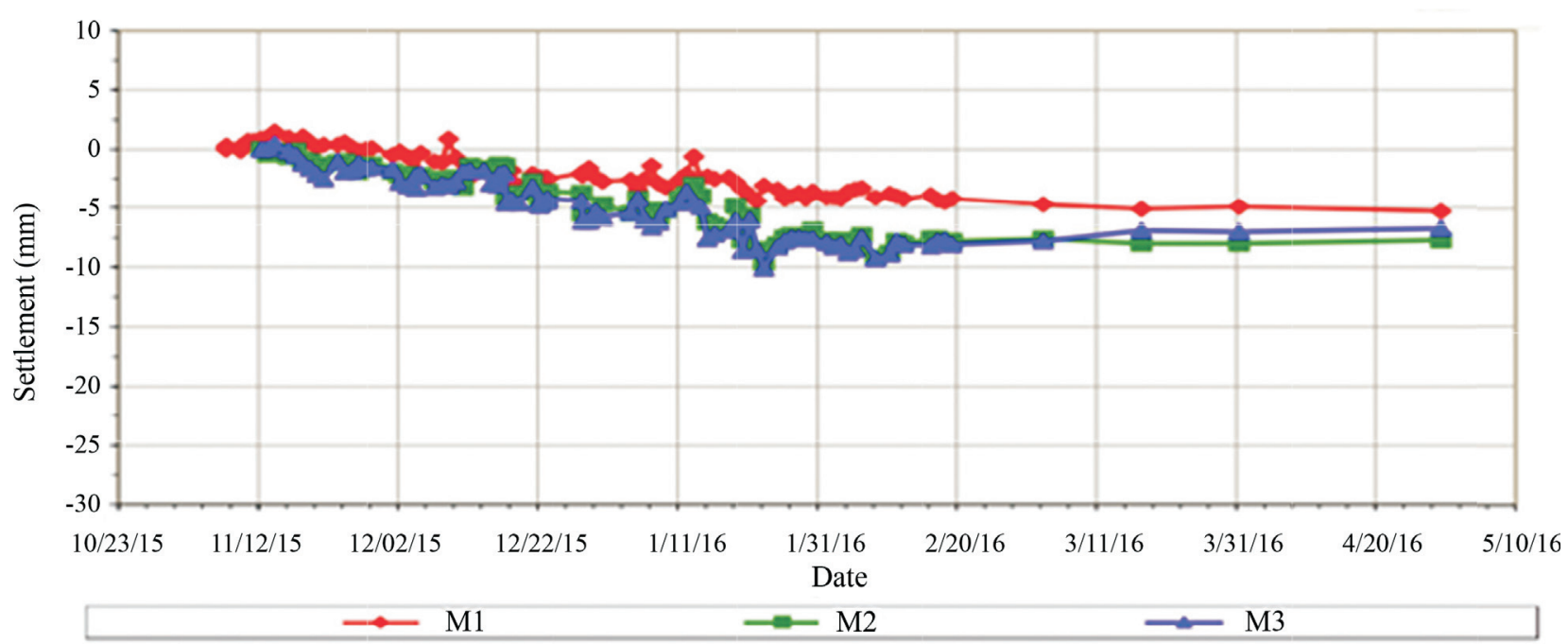

Figure 12 - Settlement (m) vs. Time (s) chart generated by surface marks M1, M2, and M3 data. Figure 5 shows these marks.

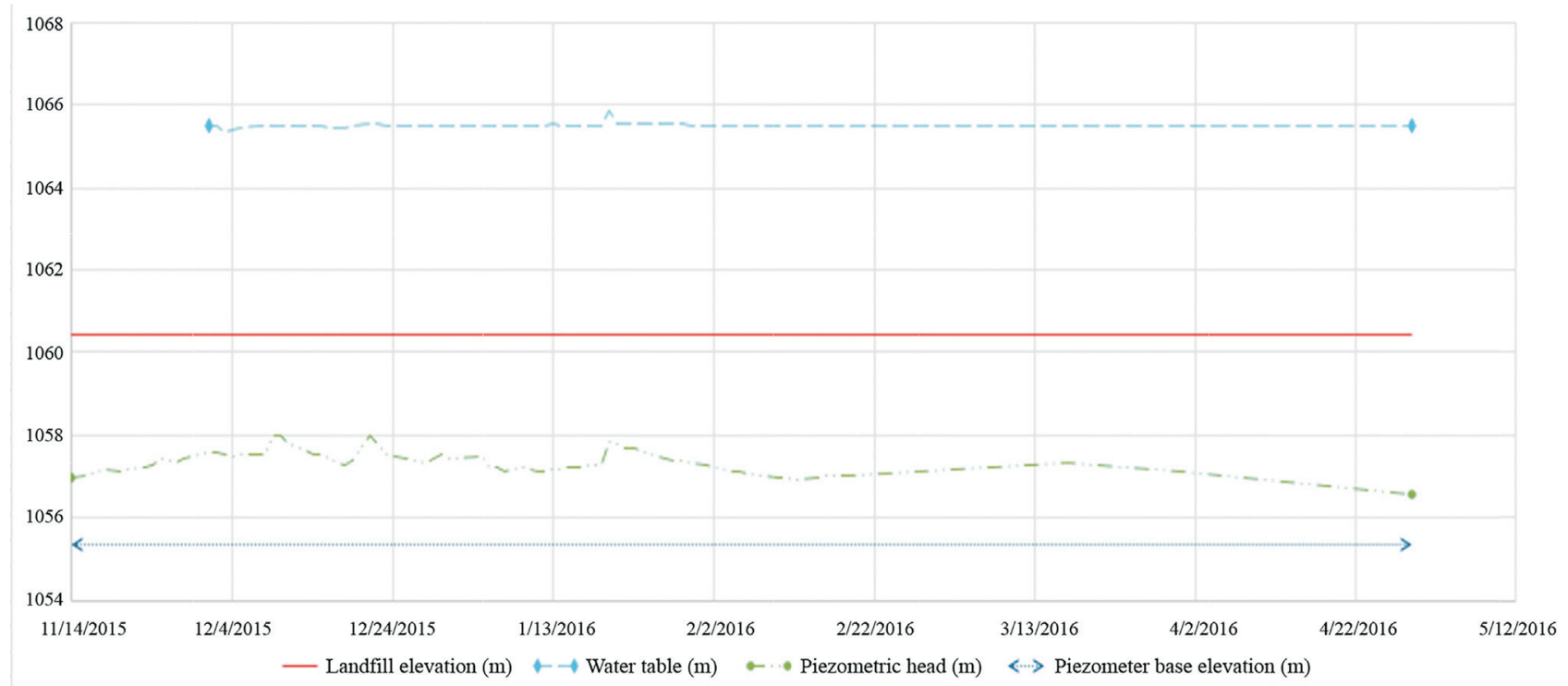

Figure 13 - Elevation (m) vs. Time (s) chart generated by the data collected by the electric piezometer 13 (P13), located on Peg 9+00 m.

due to long tree roots existing downstream of the dam. In addition to the concern regarding the anthill and the unpredicted voids, the peat layer presented thickness worryingly greater than forecasted by the geotechnical investigations.

Thus, regarding the analysis of these additional data which allowed to conclude that the original situation had worsened, the Jet Grouting treatment process had to be temporarily halted in this region, and consolidation grouting of the area was made. This consolidation was executed with a similar methodology to dams' foundations grout cut-offs to avoid possible new paths of preferential seepage and to fill the soil cavities in the affected stretch. The injections were composed of a cement slurry and injected at low pressures, as recommended by Zirlis et al. (2015).

To monitor the effect of the new treatment on the dam and the effectiveness of the grout injections, charts which correlated the volume of injected grout with the topography were made from the injection reports (Zirlis et al., 2015), as illustrated in Fig. 16.

Upon visual observation of the work, from the instrumentation data analysis and the grout injections reports, it was possible to conclude that the treatment was effective; thus, the Jet Grouting intervention in this region was resumed, as it was, finally, enough consolidated. 


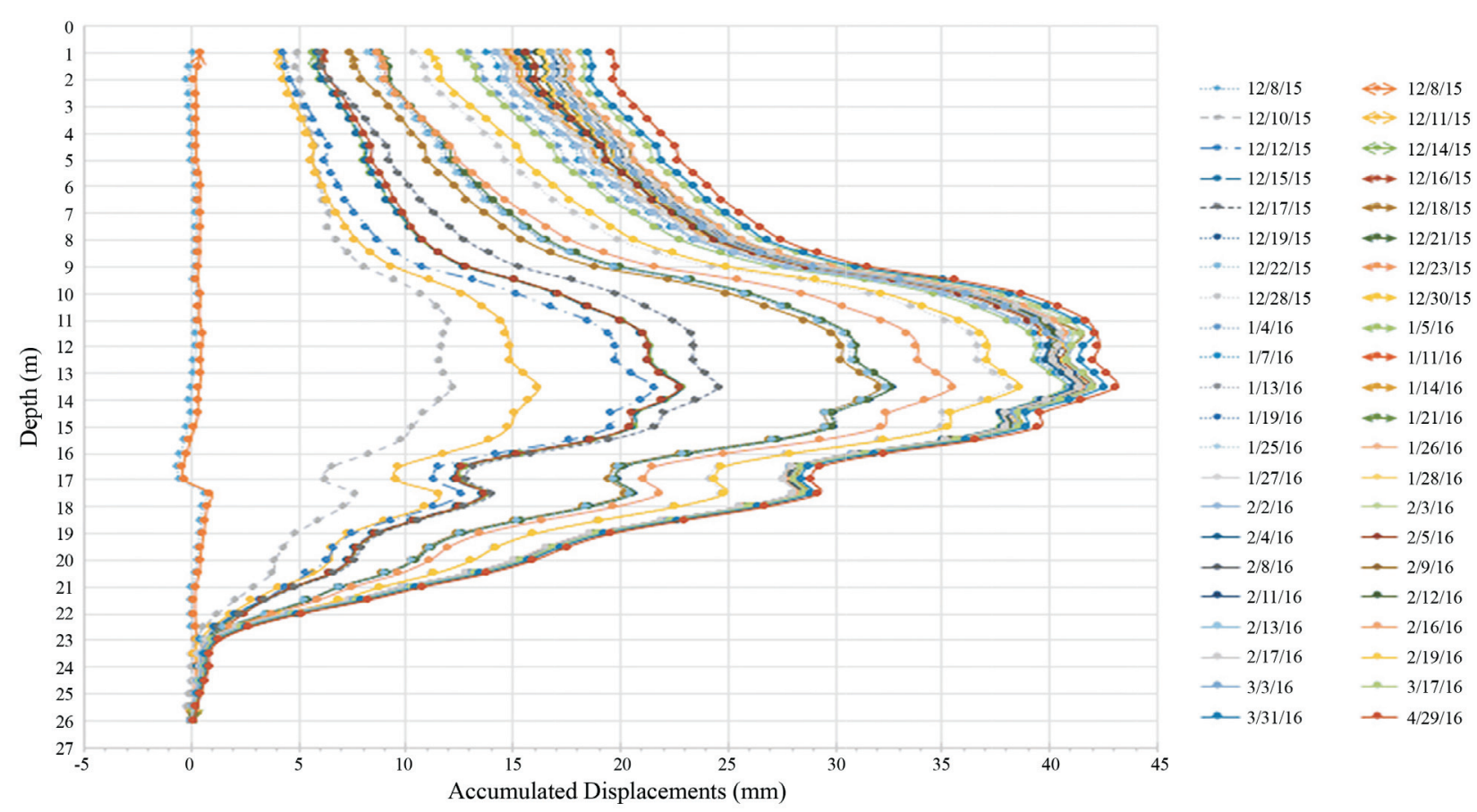

Figure 14 - Example of Depth (m) vs. Displacement (mm) chart from accumulated data generated by inclinometers in the longitudinal direction of the water flow. Different lines and symbols represent each measurement day.

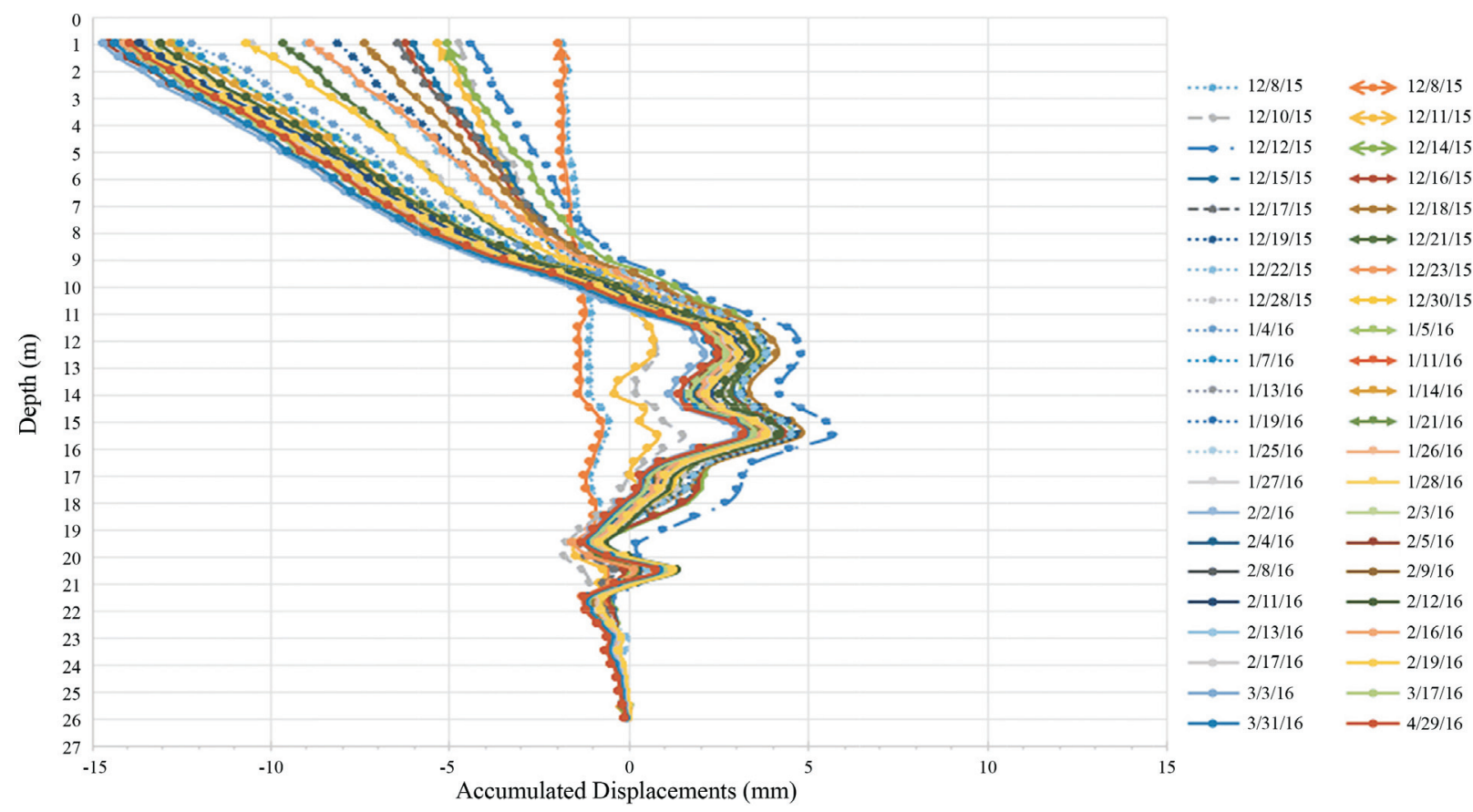

Figure 15 - Example of Depth $(\mathrm{m})$ vs. Displacement $(\mathrm{mm})$ chart from accumulated data generated by inclinometers in the normal direction of the water flow. Different lines and symbols represent each measurement day.

\section{Results}

\subsection{Initial considerations}

The success of geotechnical works is quite complex to be assessed. As ground is usually an anisotropic medium, heterogeneous, particulate and presenting non-linear behavior, obtaining genuinely representative parameters of the executed work would require a larger sample than financially allowed. Thus, the evaluation of the effectiveness of the recovery of "Ribeirão do Gama" dam assumes that a macroscopic analysis is sufficient for the problem. 


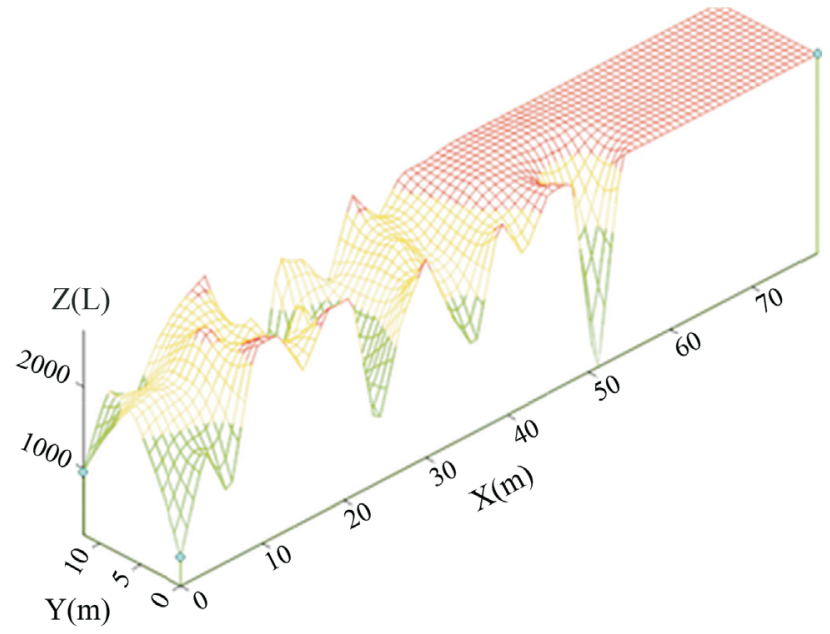

Figure 16 - Grout injection control. $Z$ axis in total grout liters injected.

\subsection{Obtained parameters evaluation}

For assessing if the recovery of the "Ribeirão do Gama" dam was successful, the resulting parameters of the executed treatment were evaluated and compared with those previously estimated in the design phase. Thus, besides the observation of instrumentation data and a detailed visual analysis, samples of $15 \mathrm{~m}$ from four columns (1\% of the total) were taken and analyzed regarding their degree of fracturing. In these four columns, which were selected in the passages in which there was more significant uncertainty regarding the formation and integrity of the soilcement, tests of water loss were conducted, with methodology adapted from Porto (2002).

As for the instrumentation, the data collected by the electric VW piezometers provided the main indication of the effectiveness of the designed cut-off waterproofness. There were points in the dam, near the spillway, where the water level was below the depth of piezometer tips; therefore, the piezometers did not detect any water head. In other piezometers, hydraulic load values obtained were many times smaller than the expected in the design phase, a fact that attested to the proper overlapping of the Jet Grouting columns and the appropriate level of waterproofing provided by the treatment.

Surface measurements were made to assist the visual analysis, done with the main objective of evaluating the diameter of the column, expected to be $0.8 \pm 0.1 \mathrm{~m}$. Although the measurement of the surface diameter of the columns does not give a clear indication of the size of the lower portion of the columns, this information, along with the hydraulic load measured at the dam's downstream, was enough to indicate there was sufficient overlapping between the columns.

The design predicted the diameter of the lower portion of the columns would have sufficient size to provide overlapping between them. This expectation justifies itself due to the fact the earth mass, until the saprolite layer depth, had a resistance low enough for the Jet Grouting process to form columns of more than $0.8 \mathrm{~m}$ diameter. Still, there was doubt whether the executed columns had an appropriate degree of impermeability. For this, in addition to the analysis of piezometric data, the fracturing of the column cores and the results of the water loss tests performed in the four sampled columns were analyzed.

For the evaluation of the fracturing and quality of core samples from Jet Grouting columns, Yoshitake et al. (2003) proposed an alternative to the RQD method: the CRI (Core Recovery Index). This approach, idealized from the RQD classification, is based on visual examination of Jet Grouting column cores. Yoshitake et al. (2003) showed a correlation of uniaxial resistance to different types of cores. In this work, although our main concern was with the permeability coefficient, the presentation of the classification of the cores withdrawn is justified by the data generation for future CRI correlations with the permeability parameter of the sample and because the CRI also has a qualitative nature.

Therefore, from the analysis of four cored boreholes, one exemplified in Fig. 17, the quality of the samples with $0.1 \mathrm{~m}$ diameter extracted using rotary core drilling equipment was evaluated regarding the general appearance of the treatment.

The analysis, based on the CRI evaluation method, indicated high-quality treatment samples at a depth of $9.1 \mathrm{~m}$, with a majority share of level 1 material (few cracks, solid and predominantly homogeneous) and level 2 material (presence of clay fractions). After this stretch, there is the peat layer; although the execution could make columns of the required diameter, there is the presence of material level 3, of fractured nature. Anyway, according to CRI criteria, the executed treatment can be characterized as highquality.

However, for obtaining the permeability coefficient, the methodology adapted from Porto (2002) was used. The Jet Grouting columns were tested each $3 \mathrm{~m}$, measuring water losses in 5 sections, totaling $15 \mathrm{~m}$ of depth. In each $3 \mathrm{~m}$ section, upward pressures, with a value multiple of $25 \mathrm{kPa}$, until obtaining a peak value of $150 \mathrm{kPa}$, were applied and then decreased to analogously correspondent pressures until reaching the previous minimum value of $25 \mathrm{kPa}$.

In the four tested drilled boreholes, the highest specific water loss was $1.98 .10^{-6} \mathrm{~m}^{3} / \mathrm{s} / \mathrm{m} / \mathrm{kPa}$, in column 317 , in the passage between 3 and $6 \mathrm{~m}$, where peat occurred. Among the tested columns, the highest permeability had a magnitude of $10^{-6} \mathrm{~m} / \mathrm{s}$, again in the section where peat existed. In the piezometers, it is clear there was a load drop in the readings of instruments downstream of the executed Jet Grouting columns, but this fall was less than expected by the model adopted. Still, the executed treatment proved entirely satisfactory, having the resurgences of water down- 


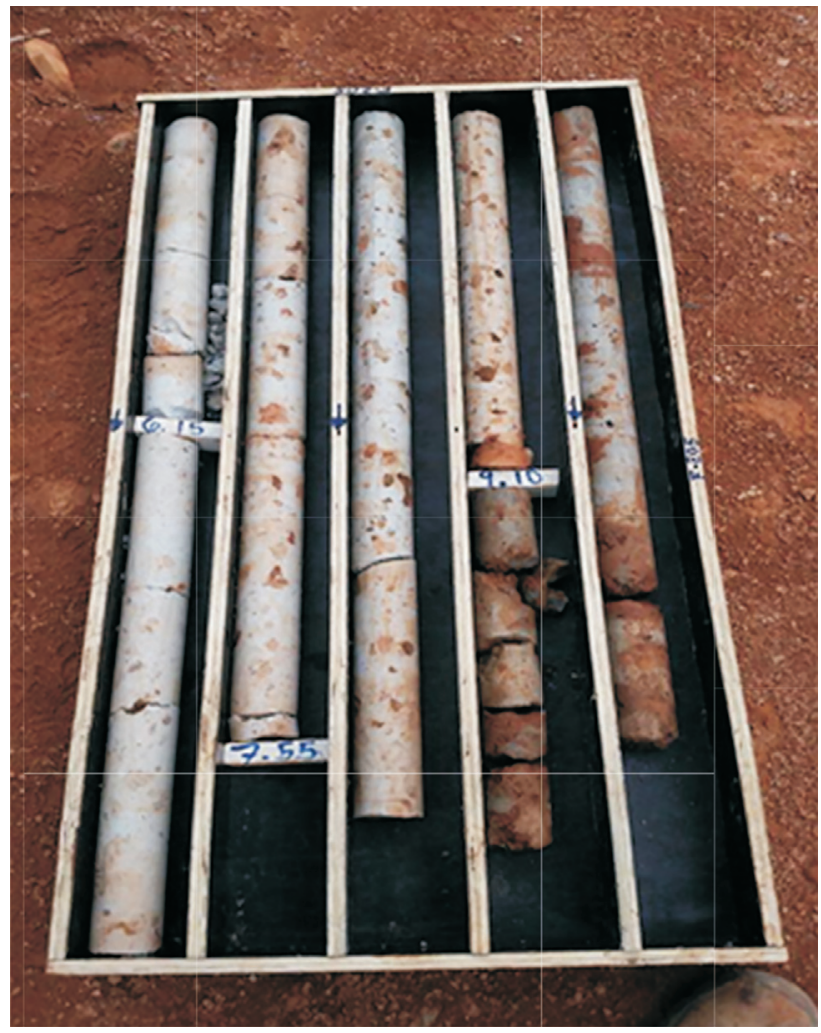

Figure 17 - Core sample from rotary drill borehole the Jet Grouting column number 186 (from the 706 executed).

stream ceased completely by the time of its completion in June 2016.

To complement the data and assess the current performance of the dam, further measurements were performed in the piezometers in October 2017, two years after the beginning of the treatment. Table 5 summarizes the results.

It is evident there was a further water head drop in the readings of instruments downstream of the executed Jet Grouting columns, even though the measurements were incomplete due to vandalism and obstructions in the piezometers. This further head drop is probably related to the slower dissipation of pore pressures in the peat layers.

\section{Conclusion}

It is advisable to inspect geotechnical works routinely after its implementation, especially dams as required by Brazilian laws. It was in one of these inspections the exposed problem was detected promptly, avoiding an accident which could have catastrophic consequences.

A successful geotechnical design depends fundamentally on proper diagnosis, which must be based on visual inspection and if possible in field and lab tests to obtain adequate constitutive parameters.

The execution of the proposed works must be monitored using the proper installation of specially selected monitoring and control instruments, allowing adjustments
Table 5 - Piezometer readings before and after the intervention.

\begin{tabular}{lcccc}
\hline $\begin{array}{l}\text { Piezo } \\
\text { meter }\end{array}$ & $\begin{array}{c}\text { Peg } \\
(\mathrm{m})^{*}\end{array}$ & $\begin{array}{c}\text { Piezometer } \\
\text { depth }(\mathrm{m})\end{array}$ & $\begin{array}{c}\text { Water level re- } \\
\text { corded before } \\
\text { treatment }(\mathrm{m})\end{array}$ & $\begin{array}{c}\text { Water level } \\
\text { recorded after } \\
\text { treatment }(\mathrm{m})\end{array}$ \\
\hline P1 & $2+0.00$ & 6.68 & 4.20 & 6.68 (Dry) \\
P2 & $5+0.00$ & 15.33 & 2.90 & N.A. \\
P3 & $9+0.00$ & 22.10 & 6.00 & N.A. \\
P4 & N. I. & 4.18 & 1.70 & N.A. \\
P5 & N. I. & 3.35 & 1.60 & N.A. \\
P6 & N. I. & 3.45 & 3.20 & N.A. \\
P7 & $15+0.00$ & 7.70 & 2.90 & N.A. \\
P8 & $15+0.00$ & 9.85 & 2.90 & 7.20 \\
P9 & $9+0.00$ & 10.00 & 4.20 & 7.05 \\
P10 & $5+0.00$ & 11.30 & 4.10 & 7.17 \\
P11 & $2+10.00$ & 3.75 & 2.00 & N.A. \\
P12 & $5+0.00$ & 12.60 & 1.00 & N.A. \\
P13 & $9+0.00$ & 16.20 & 1.14 & N.A. \\
P14 & $15+0.00$ & 8.14 & On top & N.A. \\
\hline
\end{tabular}

Peg: Piezometer location, e.g. $2+0.00 \mathrm{~m}$ represents $40 \mathrm{~m}$ from datum.

N.I.: Not informed in Fig. 5.

N.A: Not available due to vandalism or obstruction.

to the original design as soon as required to keep the execution phase safe and to minimize the probability of failure of the executed works.

In the present case study, the treatment of a piping process using a Jet Grouting cut-off with an adequate degree of waterproofing has shown to be satisfactory as the treatment eliminated downstream points of upwelling water.

The proposed solution also had a downstream toe drainage system which would be responsible for conducting the remaining flow by a proper path, after the completion of the treatment. This redundancy is necessary for situations like these because even if a failure occurred in the Jet Grouting impervious system, the resulting flow from this failure would be collected by the downstream drainage system, which would adequately conduct the flow to the natural bed of "Ribeirão do Gama", without impacting the stability of the embankment.

\section{Acknowledgments}

The authors acknowledge the data provided by the companies Tüv Süd Bureau, Solotrat, and Trier. The authors also would like to give special thanks to the contracting engineer Max V. R. Barbosa, from Solotrat, for the execution guidance, details, and parameters. Finally, the authors acknowledge the support of the following institutions: the Brazilian National Council for Scientific and Technological Development (CNPQ) (Project 
304721/2017-4), the Coordination for the Improvement of Higher Level Personnel (CAPES), and the University of Brasília for funding this research.

\section{References}

ABEF (2012). Manual de Execução de Fundações e Geotecnia - Práticas Recomendadas. Pini, São Paulo, pp. 441-466.

AGI (2012). Raccomandazioni Sul Jet Grouting. Ed. AGI, Roma, 74 p.

Bassett, R. (2012). A Guide to Field Instrumentation in Geotechnics: Principles, Installation and Reading. CRC Press, Boca Raton, pp. 3-5.

Croce, P. \& Modoni, G. (2007). Design of Jet Grouting cut-offs. In Ground Improvement, 11(1):11-20.

Guatteri, G.; Koshima, A. \& Pieroni, R.M. (2012). Challenges in execution of jet grouting curtains at the estreito HPP. In: Johnsen, L.F.; Bruce, D.A. \& Byle, M.J. (eds.) Grouting and Deep Mixing 2012. Geotechnical Special Publication No. 228. American Society of Civil Engineers, Reston, pp. 2102-2111.

Lee, W.F. \& Ishihara, K. (2016). Piping failure of a metro tunnel construction. In: Forensic Geotechnical Engineering, Developments in Geotechnical Engineering. Springer, New Delhi, pp. 433-450.

Nikbakhtan, B. \& Osanloo, M. (2009). Effect of grout pressure and grout flow on soil physical and mechanical properties in jet grouting operations. International Jour- nal of Rock Mechanics \& Mining Sciences 46(3):498505.

Perini, D.S. (2009). Estudo dos Processos Envolvidos na Análise de Riscos de Barragens de Terra. Master's Thesis, Publication G.DM-180/09, Civil and Environmental Engineering Department, University of Brasilia, $128 \mathrm{p}$.

Porto, E.C. (2002). Critério para Determinação de Vazões pela Fundação de Barragens com Base nos Ensaios de Perda d'água - O Caso da Usina Hidrelétrica de Itaipu. Master's Thesis, Federal University of Paraná, Graduate Program PPGCC/UFPR, 104 p.

Richards, K.S. \& Reddy, K.R. (2007). Critical appraisal of piping phenomena in earth dams. Bulletin of Engineering Geology and the Environment, 66(4):381-402.

Saurer, E.; Marcher, Th. \& Lesnik, M. (2011). Grid space optimization of jet grouting columns. In: Proc. 15th European Conference on Soil Mechanics and Geotechnical Engineering, 2(1):1055-1060.

Sembenelli, P. \& Sembenelli G. (1999). Deep jet-grouted cut-offs in riverine alluvia for ertan cofferdams. Journal of Geotechnical and Geoenvironmental Engineering, ASCE, 125(2):142-153.

U.S. Army illustration by Todd Plain/Released (2016). Jet Grouting Process. 2016. Web. 20 Dec. 2016.

Yoshitake, I.; Mitsui, T.; Yoshikawa, T.; Ikeda, A. \& Nakagawa, K. (2003). An evaluation method of ground improvement by jet grouting. Proceedings of the Japan Society of Civil Engineers, 735(1):215-220.

Zirlis, A.C.; Souza, G.J.T. \& Pitta, C.A. (2015). Manual de Serviços Geotécnicos. Solotrat, São Paulo, 93 p. 